\title{
A Method for the Study of the Metabolism of Isolated Mammalian Islets of Langerhans and Some Preliminary Results
}

\author{
By \\ Harry Keen, Robert Sells and R. John JarketT \\ From the Department of Medicine; Guy's Hospital Medical School, London, \\ Received February 1, 1965
}

\begin{abstract}
Summary. Isolated islets of Langerhans, micro-dissected from the duct-ligated pancreas in the rat, survived for at least four hours of incubation, their rate of glucose oxidation continuing linearly during this period. Oxidation of $1-{ }^{14} \mathrm{C}$-glucose was considerably higher when the glucose concentration in the medium was raised and com. parison with other tissue suggested that glucose oxidation of the islets, in particular that by the hexose monophosphate pathway, was specifically stimulated by the higher glucose concentrations. This may well be directly associated with the glucose stimulus to insulin release. Activity of the hexose monophosphate pathway has previously been demonstrated in both fish and mammalian islets and in human islet cell tumours, both by enzyme estimations and by studies with labelled glucose, and the suggestion has been made that activity of the pathway may be linked with insulin synthesis (FIELD, 1964).

This work was supported by Grant No. AM 6135 MET of the National Institutes of Health, Bethesda, Maryland. Our thanks are due to Dr. James B. FindD, in whose laboratories the earliest studies were initiated.

Résumé. Des îlots de Langerhans isolés par microdissection chez le rat, après ligature des canaux pancréatiques, survivent pendant au moins quatre heures d'incubation "in vitro", leur rythme d'oxydation du glucose se poursuivant d'une manière constante pendant cette période. L'oxydation du $1-{ }^{14} \mathrm{C}$-glucose était considérablement plus élevée lorsque la concentration en glucose du milieu était augmentée, et la comparaison avec le comportement d'autres tissus a suggéré que l'oxydation du glucose par les îlots, en particulier celle qui s'effectue par la voie de l'hexose monophosphate, était stimulée spécifiquement par les concentrations les plus hautes en glucose.
\end{abstract}

Based on a communication given to the Meeting of the Medical and Scientific Section of the British Diabetic Association, September, 1963.

The study of islet function in the mammalian pancreas is hindered by the dispersion of the islet tissue through the organ. Scotw (1912) first used the method of tying the pancreatic ducts to produce atrophy of the acinar tissue, and it is well known that the first elear demonstration of the hypoglycemic action of saline extracts of canine pancreas by BANTing and BEST (1922) involved the use of this technique. We have applied the same procedure in the rat to make a preparation of surviving mammalian islets for in vitro metabolic studies.

\section{Methods}

a) Duct ligation and its effects. The gross anatomy of the pancreatic ducts of the Wistar Rat is shown in Fig. 1, a drawing made after injecting Indian ink through the common bile duct. In over a dozen such
Ce phénomène pourrait bien être directement associé avec le stimulus que le glucose exerce pour libérer l'insuline. L'activité de la voie de l'hexose monophosphate a été antérieurement démontrée à la fois sur les îlots de poisson et de mammifère ainsi que sur les cellules de tumeurs insulaires humaines, à la fois par des estimations enzymatiques et par des études effectuées avec du glucose marqué, et la suggestion a été faite que l'activité de cette voie métabolique pouvait être liée à celle de la synthèse de l'insuline (FIELD, 1964).

Zusammenfassung. Nach Ligatur der Pankroasausführungsgänge bei der Ratte durch Mikrodissektion gewonnene Langerhans'sche Inseln können durch Inkubation in vitro am Leben erhalten werden und bleiben für mindestens 4 Stunden in der Lage, Glukose mit konstanter Geschwindigkeit zu oxydieren. Eine Erhöhung der Glukosekonzentration des Mediums führt zu einer beträchtlich gesteigerten Oxydation der Glukose-1-14C. Diese Stimulierung der Glukoseoxydation durch die Inselzellen scheint selektiv zu sein, wie der Vergleich mit der Stimulation, die man unter den gleichen Bedingungen durch andere Gewebe erhält, annehmen läßt. Besonders die direkte Oxydation des Glukose-6-phosphats scheint gesteigert zu sein. Es ist möglich, daß dieser Stoffwechseleffekt von einer durch Glukose gesteigerten Insulinsekretion begleitet wird. Das Vorhandensein des Pentosezyklus in den Langerhans'schen Inseln von Fischen und Säugetieren, sowie in den Zellen von Tumoren mit Insulinaktivität ist bereits nachgewiesen worden. Diese Beobachtungen stützen sich auf enzymatische Messungen und vergleichende Stoffwechseluntersuchungen mit markierter Glukose, und es ist möglich, daß die Aktivität des Pentosephosphatzyklus mit derjenigen der Insulinsynthose verknüpft ist. (FLELD, 1964) preparations, the arrangement of the ducts was remarkably constant. There are two main ducts, both draining into the bile duct. The upper drains the gastric and splenic portions of the pancreas and the lower drains that part of the pancreas lying below and behind the transverse colon. In preliminary experiments it was found that the lower duct was technically more difficult to locate and tie. Subsequently, therefore, the upper duct only was tied.

Male rats were anaesthetised with ether and the pancreas exposed, through a median ventral incision, by drawing out the stomach and duodenum and turning them back on to the chest wall. Under the dissecting microscope (magnification $\times 25$ ) the upper duct was identified and two or three ligatures of fine silk tied in approximately the positions shown in Fig. 1. The organs were then replaced and the wound closed. The operated rats were killed at two or three day intervals and the pancreas fixed in 10\% formol-saline. Paraffin sections were stained with haematoxylin and eosin and examined systematically under the light microscope. 
b) Metabolic Studies. These were carried out using islets removed from rats operated upon four to six weeks previously. The atrophic portion of the pancreas was readily identified, the normal, pink, fleshy acinar tissue being replaced by glistening, transparent

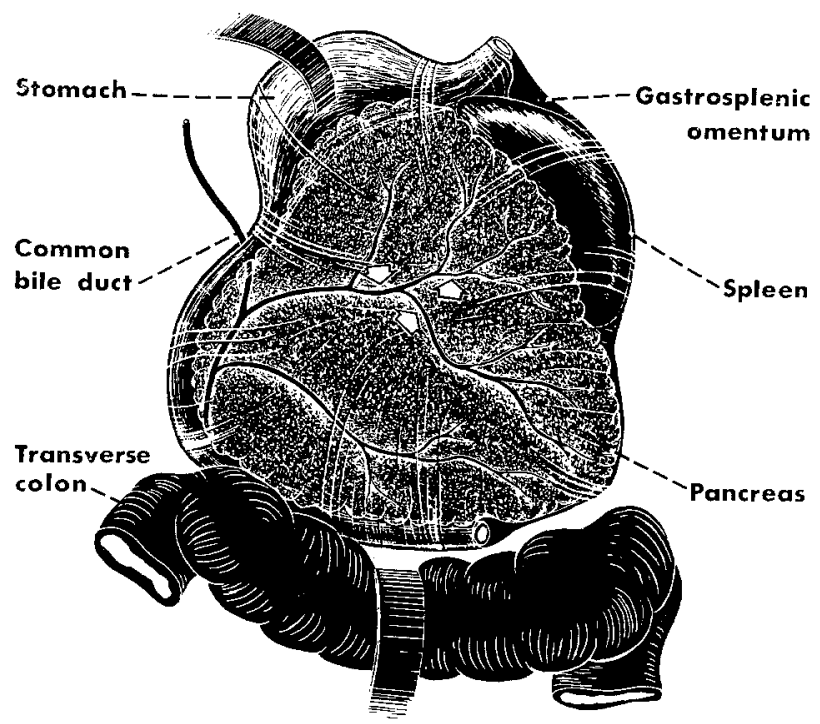

Fig. 1. Pancreatic ducts of the Wistar rat. Drawing of a specimen injected in vivo with Indian ink through the common bile duct. Arrows indicate sites of ligation
They have a peculiarly speckled appearance, due to the many small capillaries coursing over the surface and penetrating between the cells. An individual islet was removed by grasping with the forceps the fine, duct-like cord of connective tissue to which it is attached (Fig. 2). Care was taken not to grasp the fragile islets between the forceps. After removal, the cleaned islets (Fig. 3) were collected in a small, black-based container, filled with chilled buffer. As each batch was completed, it was transferred to the incubation medium contained in the centre well of the micro-incubation apparatus previously described by KEEN et al. (1963).

Batches of ten islets were incubated in $0.15 \mathrm{ml}$ of KREBS-RINGER bicarbonate buffer together with ${ }^{14} \mathrm{C}$ labelled glucose and unlabelled glucose. The reaction was stopped and ${ }^{14} \mathrm{CO}_{2}$ expelled from the medium by the injection of $0.1 \mathrm{ml} \mathrm{N} / 10 \mathrm{HCl}$ into the centre well. The ${ }^{14} \mathrm{CO}_{2}$ was collected, during one hour's diffusion at room temperature, in $1 \mathrm{ml}$ of phenylethylamine solution (Woeller, 1961), injected into the vial base at the end of incubation. The phenylethylamine solution with its content of ${ }^{14} \mathrm{CO}_{2}$ was then added to $10 \mathrm{ml}$ of phosphor (0.3\% P.P.O. in xylene) and counted in a liquid scintillation counter (Nuclear Enterprises, Ltd.,). After removing the islets, the residual incubation medium was neutralised with $0.1 \mathrm{ml} \mathrm{N} / 10 \mathrm{NaOH}$, and stored at $-20^{\circ} \mathrm{C}$ for the subsequent determination of

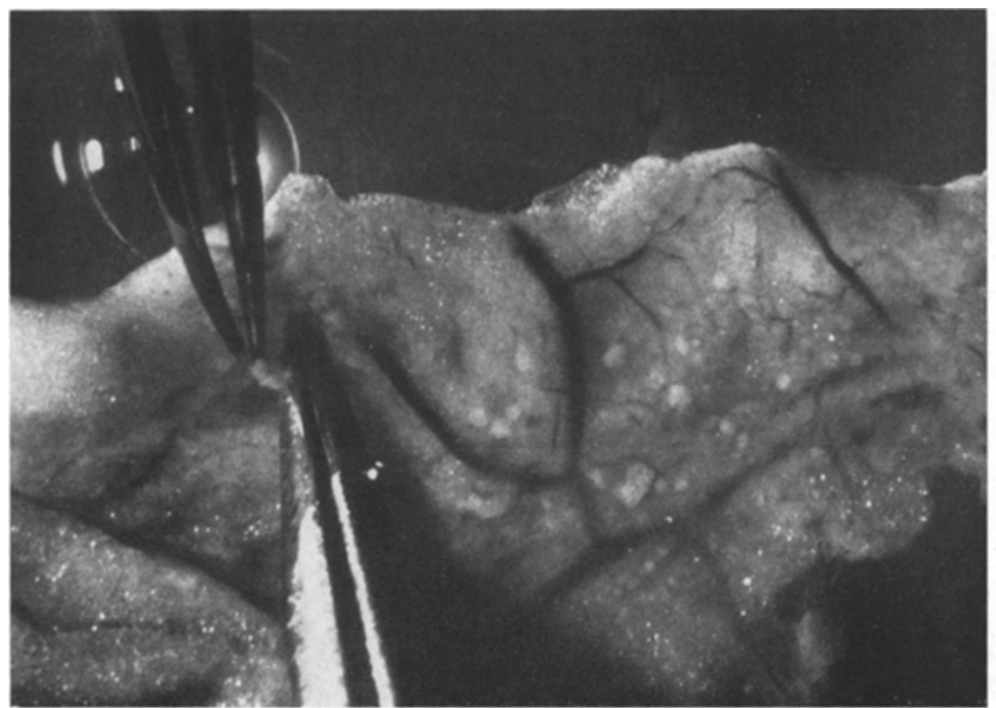

Fig. 2. Acinar atrophy. Photograph of rat pancreas four weeks after duct ligation. The islets appear as solid, ovoid bodies against the translucent fat. The forceps grasp a connective tissue cord to which an islet is attached

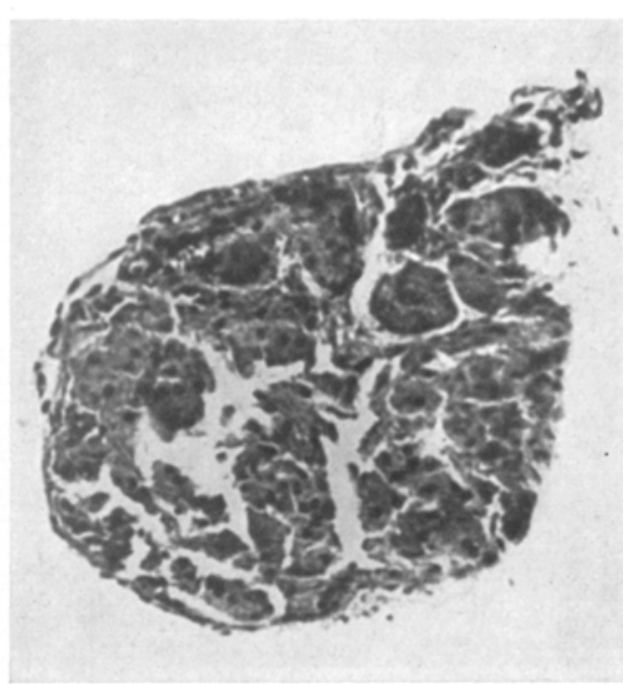

Fig. 3. Isolated rat islet $(\times 500)$. Photomicrograph of $\mathrm{mi-}$ crodissected islet. Below, right, is the connective tissue skeleton, by which the islet is handled fat. After the atrophic zone was detached from the rest of the pancreas it was transferred to a black-based Petri dish containing chilled Krebs-Ringer bicarbonate buffer and teased apart under the dissecting microscope (magnification $\times 25$ ), using fine watchmaker's forceps. The islets are ovoid, sometimes lobed bodies, often clustered in groups, and pale and solid in appearance against the translucent, fatty background (Fig. 2). its insulin content, which was carried out by a modification of the rat epididymal fat pad assay of MARTín et al. (1958).

\section{Resulls}

a) Histology. Our early experience with duct - tied rats showed that only about $20 \%$ of rats killed six or more weeks after operation showed the necessary fatty 


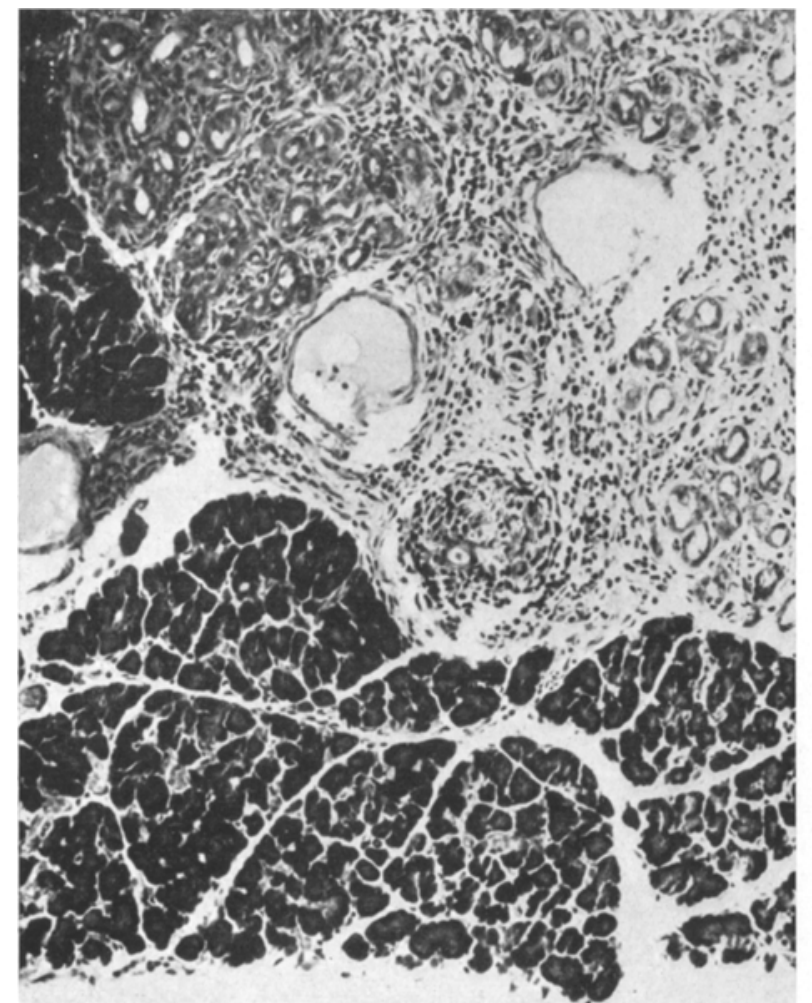

Fig. 4. Rat pancreas: 7 days after ligation $(\times 200)$. In the lower part of the photograph, the panereas is normal; above it is partially atrophied, with cystic areas

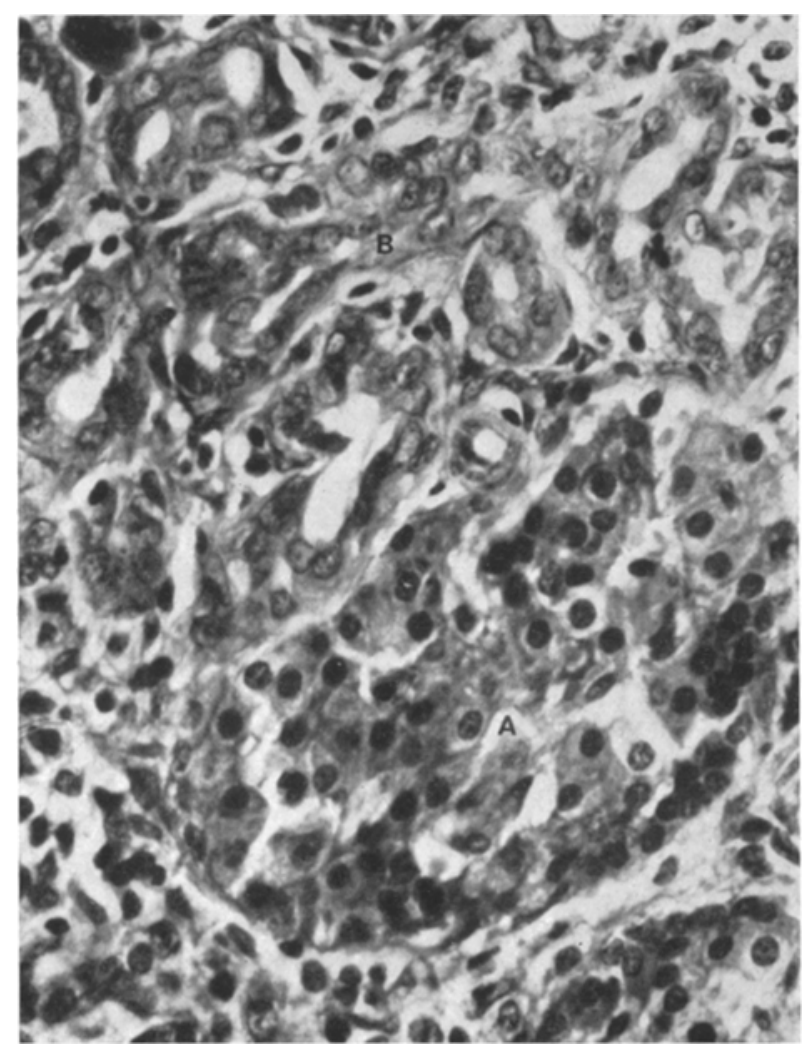

Fig. 5. Rat pancreas: 10 days after ligation ( $\times 720$ ). Abnormal islet (A) in region of cystic atrophy (B). Note the wide capillary spaces

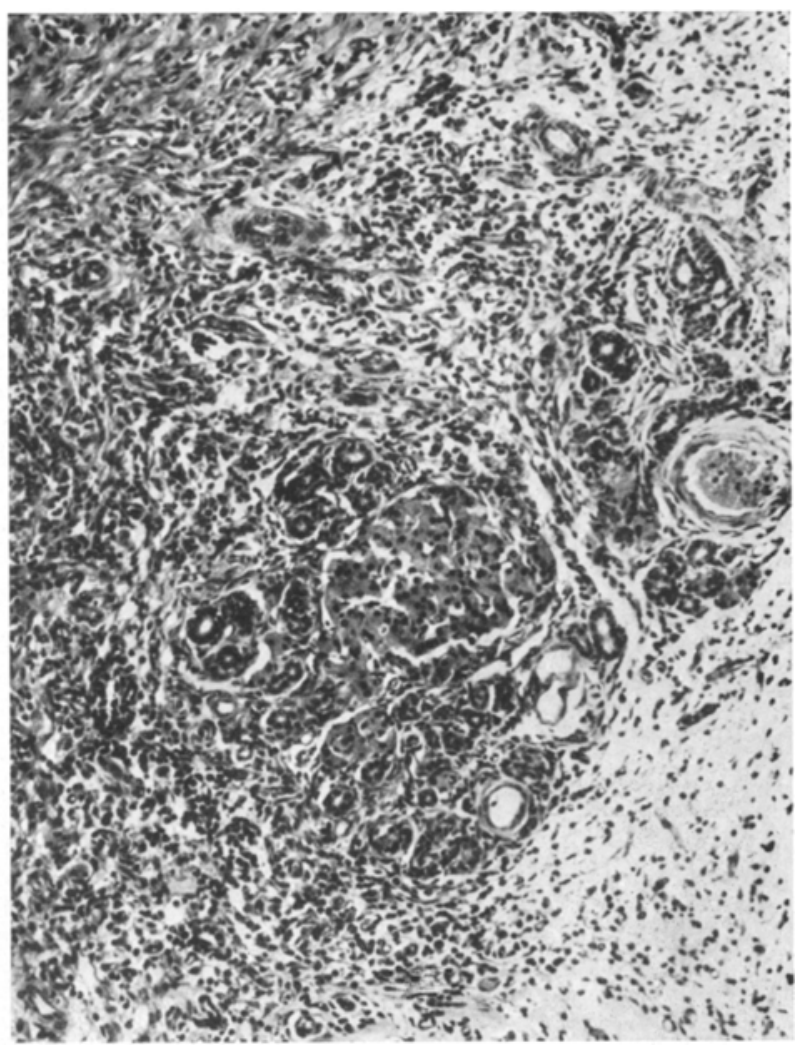

Fig. 6. Rat pancreas: 13 days after ligation $(\times 200$ ). An area of regeneration (centre) of both islet and acinar tissue in a region of atrophy and fibrosis

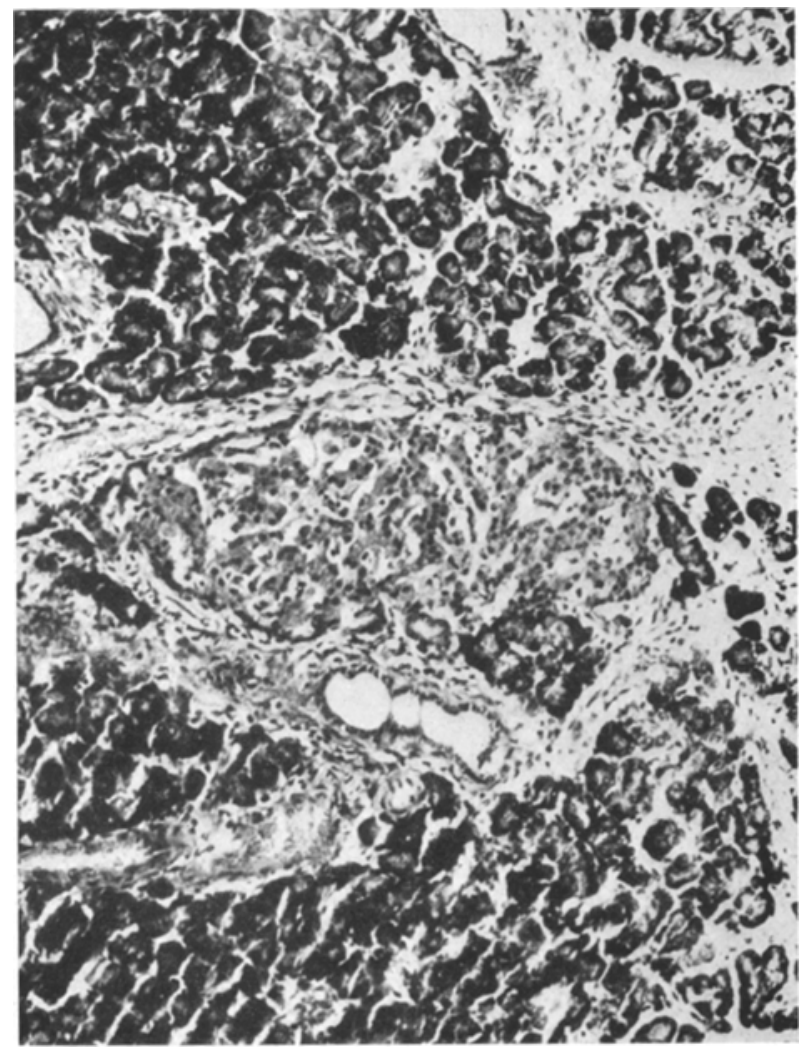

Fig. 7. Rat pancreas: 24 days after ligation $(x 200$ ). Regeneration of a acinar tissue has occurred. The hypertrophied islet (centre) is demarcated by a capsule of connective tissue 
replacement of acinar tissue. Consequently, systematic studies of pancreatic histology at varying intervals after ligation were undertaken:

1-4 days: The lobe behind the ligature showed several changes. At its centre there was necrosis of the acini and the islets, though islet cell 'ghosts' persisted. In the surviving cells, zymogen granules were scanty and the nuclei were poorly defined. At the periphery, both acinar and islet cells were swollen and capillaries were partially obliterated. Infiltration of leucocytes and exudate was seen around and at the periphery of the lobe.

4-10 days: Necrosis of the central acini was more advanced, with fibrous infiltration but persistence of islet cell ghosts. Peripherally, there was well-marked cystic acinar dilatation (Fig. 4), with few granules visible, loss of nuclear profile, cloudy swelling of the cytoplasm and pale staining. In general, there was enlargement of the islets, but the capillaries appeared to be wide open (Fig. 5). Towards the tenth day the appearance of the peripheral islets was normal.

10-17 days: Amid the fatty replacement of the necrotic acinar tissue there were foci of regenerating acinar and islet cells. The peripheral acinar tissue was still cloudy, but granules were reappearing. Cystic ducts were plentiful. (Fig. 6).

$17-24$ days: The regenerating foci of acinar tissue were now proliferating. In later sections, normal acinar tissue was seen interspersed with scarred glands and eystic ducts. Islets were sparse in the regenerating areas. In some later sections, however, individual islets were seen regenerating, embedded in fat or fibrous tissue and apparently with an increased blood supply (Fig. 7).

It was concluded that, in many of the apparently unsuccessful ligation experiments, drainage of the affected lobe had been re-established via collateral ductules, with repopulation of the lobe by acinar tissue. Examination of several specimens under the dissecting microscope supported this view, for in many cases, the ligatures, which had most certainly invested the main ducts, were now to be found lying free in the tissue, with a few strands of fibrous tissue within the knot. It would appear, from the above studies, that the ideal time to use the duct-tied animals is $2-4$ weeks after operation.

b) Metabolic Studies. Batches of ten islets were incubated with $1{ }^{14} \mathrm{C}$-glucose for varying periods of up to four hours at $37^{\circ} \mathrm{C}$ in a shaking incubator. Fig. 8 demonstrates that the oxidation of glucose to $\mathrm{CO}_{2}$ continued in a linear fashion for four hours of incubation. Assay of the insulin content of the incubation medium (Fig. 9) showed that considerable amounts of insulin had been released. Allowing for dilution, the actual insulin concentration in the incubation media was estimated as $5-50 \mathrm{mu} / \mathrm{ml}$.

In further experiments, groups of islets were incubated in glucose concentrations of 40 and $400 \mathrm{mg} \%$ respectively. The specific activity of the $1 .{ }^{14} \mathrm{C}$-glucose was the same in each case $(10 \mu \mathrm{c} / \mathrm{mg})$. In one experiment for comparison, $20 \mathrm{mg}$ pieces of rat epididymal fat were also incubated at these two glucose concentrations. The amounts of ${ }^{14} \mathrm{CO}_{2}$ produced are shown in Fig. 10. In the high glucose medium, the islets produced

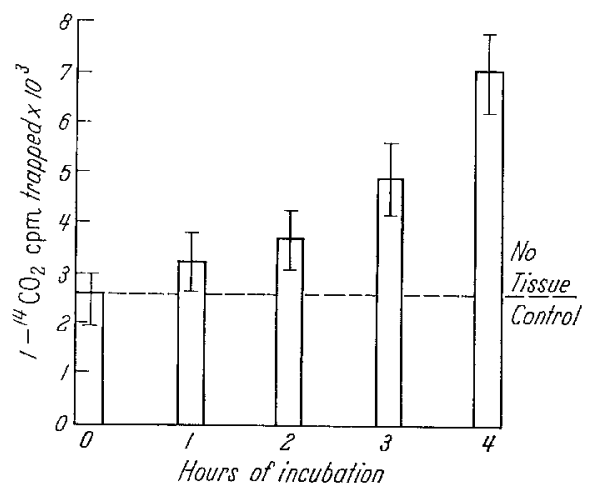

Fig. 8. The effect of duration of incubation upon ${ }^{14} \mathrm{CO}$, production from

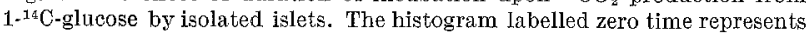
the value for medium incubated without islets

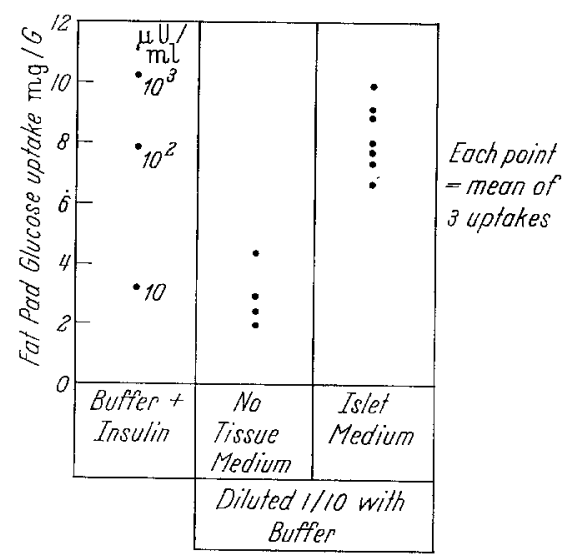

Fig. 9. Assay of the insulin-like activity of the incubation media from the experiment depicted in Fig. 8 . The assay is based upon the glucose uptake of rat epididymal fat

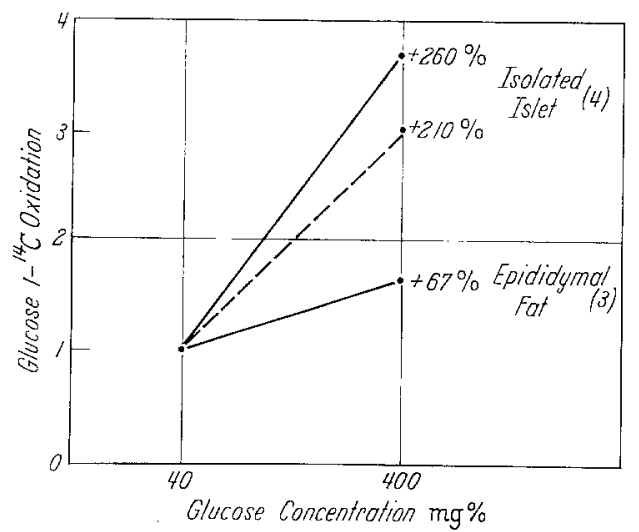

Fig. 10. The effect of glucose concentration upon ${ }^{14} \mathrm{CO}_{2}$ production from 1-14 $\mathrm{C}$-glucose by isolated islets of Langerhans and rat epididymal fat, respectively. The solid lines represent an experiment in which islets and fat were directly compared. The broken line represents a further experiment, in which islets alone were incubated. Three separate pieces of fat and two batches of islets were incubated at both high and low glucose concentrations for three hours 
four times as much ${ }^{14} \mathrm{CO}_{2}$ as in the low glucose medium, a much greater increase than that seen with the epididymal fat, suggesting that high glucose concentrations may have had a specific stimulatory effect on oxidative mechanisms within the islet. A further experiment compared the rate of oxidation of ${ }^{1-14} \mathrm{C}$-glucose by islets incubated at glucose concentrations of 20 and $200 \mathrm{mg} \%$ respectively, with that of small fragments of rat pancreatic fat of similar dimensions to the islets, taken from the atrophic pancreas adjacent to them and incubated under the same conditions. Fig. 11 shows the striking difference between the two tissues.

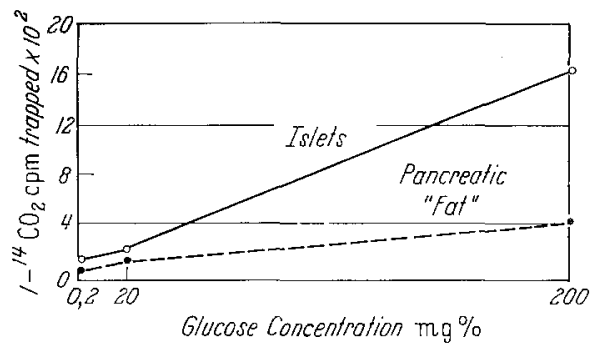

Fig. 11. A comparison of the effect of glucose concentration upon the production of ${ }^{14} \mathrm{CO}_{2}$ from $1{ }^{14} \mathrm{C}$-glucose by isolated islets and by fragments of pancreatic fat, respectively. Two batches of islets and two of fat fragments were incubated at each of three concentrations of glucose for three hours

Table. Glucose concentration and 1-C and 6-O oxidation

\begin{tabular}{c|cc|c}
\hline & \multicolumn{2}{|c|}{$\begin{array}{c}\text { cpm from } \\
1-{ }^{14} \mathrm{CO}_{2} 6-{ }^{14} \mathrm{CO}_{2}\end{array}$} & $1 / 6$ \\
\hline $20 \mathrm{mg} \%$ medium & 1256 & 948 & 1,3 \\
$200 \mathrm{mg} \%$ medium & 9288 & 3697 & 2,5 \\
\hline $200 / 20$ & 7,4 & 3,9 & \\
\hline
\end{tabular}

Finally, the ${ }^{14} \mathrm{CO}_{2}$ production by isolate dislets from $1{ }^{14} \mathrm{C}$-glucose was compared with that from $6-{ }^{14} \mathrm{C}$-glucose in low and high glucose concentrations (20 and $200 \mathrm{mg} \%$ ). Table 1 shows that ${ }^{14} \mathrm{CO}_{2}$ production was greater in the high glucose medium in both cases, but that the relative increase was greater in the case of the glucose labelled in the 1 position.

\section{Discussion}

Several approaches have been used in the study of $\beta$-cell metabolism and its relationship to insulin synthesis and release (FíELD, 1964). A great deal of infor. mation has been gained from the study of the "principal islet" of teleost fish, but it appears that there may be important differences between the piscine and the mammalian islet. Studies of insulin production using perfused pancreas (Grodsky et al., 1963), or pieces or slices of pancreas (CooRE and RANDLE, 1962; R-CANDELA et al., 1963) from mammals have been reported; MíalHe and Meyer (1961) used pieces of duct-tied rat. pancreas. However, because of the overwhelming excess of acinar tissue present, it is not possible with these techniques to study the related intermediary metabolism of the islets. The technique described in this paper offers a method by which both insulin production and metabolic processes can be studied simultaneously.

Since this work was begun, HeLLERSTrom (1964) has described a method for the micro-dissection of islets in the mouse, rat or guineapig without prior duct ligation. Having since tried both methods, we feel that removal of the islets is easier and quicker if the ducts are first tied. This is of some importance, in that $80-100$ islets are required for the average experiment. In addition, there is the further advantage of working with tissue certainly uncontaminated by proteolytic enzymes from the exocrine pancreas.

References. Banting, F. G. and C.H. Best: Pancreatic extracts. J. Lab. Clin. Med. 7. 464-472 (1922). - Coore H.G. and P.J. RANDLE: Secretion of insulin by rabbit pancreas in vitro. Biochem J. 84, 78P (1962). - FrELD, J.B.: Factors concerned with insulin synthesis and release. Metabolism, 13. 407-421 (1964). - Grodsky, G. M., A.A. Batts, L.L. Bennett, C. Voella, N.B. McWrLLIAMS, and D.F. SMITH, Effects of carbohydrates on secretion of insulin from isolated rat pancreas. Amer. J. Physiol. 205, 638-644 (1963). - Hetrerstrom, C.: A method for the micro-dissection of intact pancreatic islets of mammals. Acta Endocrinologica. 45, 122-132 (1964). - Keen, H., J.B. FIELd and I. PAstan: A simple method for in vitro metabolic studies using small volumes of tissue and medium. Metabolism. 12, 143-147 (1963). Martin, D.B., A.E. Renold and Y.M. Dagenais: An assay for insulin-like activity using rat adipose tissue. Lancet. 2, 76-77 (1958). - Mialhe, P. and V. MeYer: Secretion d'insuline par le pancreas du rat in vitro. C.R. Acad. Sci. (Paris). 253, 1861 - 1863 (1961). - R-CANDELA, J.L., D. Martin-Hernandez and T. Castilla-CortaZAR: Stimulation of insulin secretion in vitro by adenosine triphosphate. Nature, 197, 1304 (1963). - ScotT, E.L.: On the influence of intravenous injections of an extract. of the pancreas on experimental pancreatic diabetes. Amer. J. Physiol. 29, 306-310 (1912). - Woeller, F.H.: Liquid scintillation counting of $\mathrm{C}^{14} \mathrm{O}_{2}$ with phenylethylamine. Analyt. Biochem. 2, 508-511 (1961).

Harry KeEN, Department of Medicine Guy's Hospital Medical School London, S.E. 1.

England 